\title{
Effects of Neutral Red and Imidazole upon Insulin Secretion*
}

\author{
W. Malatsse, F. Mataisse-Lagate and S. King \\ Laboratoires de Médecine Expérimentale et d'Anatomie Pathologique, Université Libre de Bruxelles
}

Received: January 10, 1968

\begin{abstract}
Summary. The present communication deals with the possible effect of glucagon released from the alpha-cells upon insulin secretion induced by glucose in the adjacent beta-cells. First, it has been shown that neutral red, a substance which is thought to cause glucagon release from the alpha-cells, did not modify the rate of insulin secretion induced by glucose in pieces of rat pancreatic tissue. Secondly, glucose stimulated insulin secretion under conditions where imidazole, a substance known to activate the phosphodiesterase, completely abolished the stimulant effect of exogenous glucagon upon insulin secretion. It is concluded that glucagon is not necessarily involved in the stimulation of insulin secretion by glucose, and that the effect of locally released glucagon, if any, is only to enhance the stimulant action of glucose.
\end{abstract}

Effets du rouge neutre et de l'imidazole sur la sécrétion de l'insuline

Résumé. Les auteurs envisagent le rôle éventuel que joue le glucagon libéré par les cellules alpha dans la sécrétion d'insuline induite par le glucose dans les cellules beta voisines. Le rouge neutre, qui est supposé libérer le glucagon des cellules alpha, ne modifie pas la sécrétion d'insuline provoquée par le glucose dans le tissu pancréatique du rat. De plus, le glucose stimule la sécrétion d'insuline en présence d'imidazolo, un activateur de la phosphodiestérase, utilisé en concentrations suffisantes pour abolir l'effet du glucagon exogène. Ces données suggèrent que le glucagon n'est pas nécessairement impliqué dans la stimulation de la sécrétion d'insuline par le glucose, et qu'un éventuel effet du glucagon libéré localement par les cellules alpha se limite à potentialiser l'action stimulatrice du glucose.

Einwirkung von Neutralrot und Imidazol auf die Insulinsekretion

Zusammenfassung. Die Autoren untersuchten die Rolle, die das aus den $\alpha$-Zellen freigesetzte Glucagon eventuell bei der durch Glucose stimulierten Insulinsekretion aus den benachbarten $\beta$-Zellen spielt. Neutralrot soll zwar Glucagon aus den $\alpha$-Zellen freisetzen, führt aber zu keiner Änderung der glucosestimulierten Insulinsekretion des Rattenpankreas. Ferner stimuliert Glucose die Insulinsekretion, auch wenn man Imidazol, einen Aktivator der Phosphodiesterase in Mengen zusetzt, die ausreichen, um den Effekt von exogenem Glucagon zu unterdrücken. Auf Grund dieser Befunde kann man annehmen, daß Glucagon nicht notwendigerweise in die durch Glucose stimulierte Insulinsekretion eingreift und daß ein eventueller Effekt von lokal aus den $\alpha$-Zellen freigesetztem Glucagon sich auf eine Verstärkung der Stimulationswirkung von Glucose beschränkt.

Key-words: Insulin secretion, neutral red, imidazole, glucagon, theophylline.
It is now firmly established that glucagon stimulates insulin secretion both in vivo $[9,2]$ and in vitro $[10$, $12,5]$. In view of the proximity of alpha- and beta-cells within the islets of Langerhans, it has been speculated that glucagon may play a role in the normal rate of insulin secretion evoked by glucose in pancreatic tissue [4]. Further investigation of this hypothesis was hampered by our meagre knowledge concerning factors stimulating glucagon secretion by the alpha-cells and concerning drugs specifically inhibiting the effects of glucagon upon insulin secretion. It has been recently demonstrated that neutral red causes, in the rat, glucagon release from the alpha-cells [8]. It seemed therefore of interest to study the effect of neutral red upon insulin secretion induced by glucose in incubated pieces of rat pancreatic tissue. It has also been reported that imidazole activates the phosphodiesterase in homogenized or perfused heart and liver $[1,3]$. Since glucagon is thought to stimulate insulin secretion by activation of the beta-cell's adenylcyclase system [5], we

* Supported in part by a grant-in-aid from the Lilly Research Laboratories, and by the association contract Euratom-Universities of Pisa and Brussels (026-63-04 BIAC). have also investigated, in pieces of pancreatic tissue, the effect of imidazole upon insulin secretion induced by glucose, glucagon, and theophylline. It is here suggested that release of glucagon from the alphacells is not necessarily involved in the stimulation by glucose of insulin secretion from the adjacent betacells.

\section{Material and Methods}

Experimental Procedure. Pancreatic tissue was removed from normal, fed rats (ca. $250 \mathrm{~g}$ body weight), and small pieces $(4 \times 10 \mathrm{mg}$ ) incubated for $60 \mathrm{~min}$ at $36^{\circ} \mathrm{C}$ in a bicarbonate buffered medium $(2.0 \mathrm{ml})$ equilibrated with a mixture $\mathrm{O}_{2}(95 \%)-\mathrm{CO}_{2}(5 \%)$, and containing glucose $(150$ or $300 \mathrm{mg} / 100 \mathrm{ml})$, bovine serum albumin $(500 \mathrm{mg} / 100 \mathrm{ml})$, and guinea-pig anti-insulin serum (GPAIS, lot 404, prepared and kindly donated by Dr. P.H. WRIGHT, Indiana University, Indianapolis). For reasons given elsewhere [13], sufficient GPAIS was added to bind at least twice the amount of secreted insulin. Also added to the media, as required, were theophylline $(2.5$ to $25 \mathrm{mg} / 100 \mathrm{ml})$, glucagon $(1.0 \mathrm{mg} / 100 \mathrm{ml}$; beef-pork crystalline glucagon, Eli 
Lilly and Co., Indianapolis), kallikrein inhibitor ( 62500 KIU/ $100 \mathrm{ml}$; Trasylol, Bayer), neutral red (4.0 to 40 $\mathrm{mg} / 100 \mathrm{ml}$; Allied Chemical Corporation, New York),

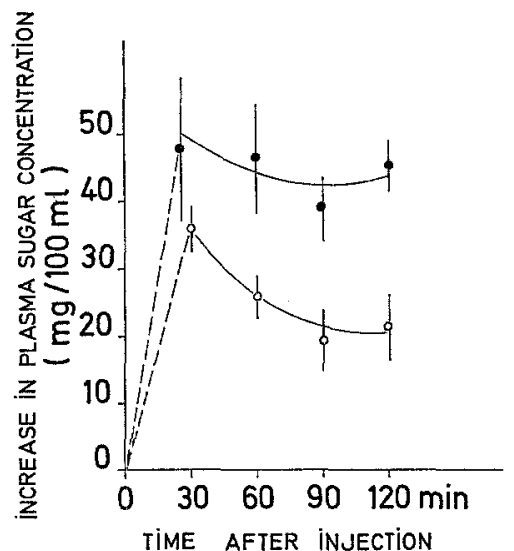

Fig. 1. Effect of neutral red (closed circles; $100 \mathrm{mg} / \mathrm{kg}$ body wt.; intraperitoneal administration at time zero) and glucagon (open circles; $1.0 \mathrm{mg} / \mathrm{kg}$ body wt.; intravenous injection at time zero) upon plasma sugar concentration $(\mathrm{mg} / 100 \mathrm{ml})$ in normal fed conscious rats. The mean values ( $\pm \mathrm{SEM}, n=3$ to 5 ) correspond to the increase in plasma sugar concentration above the pre-injection level (138 $44 \mathrm{mg} / 100 \mathrm{ml}, n=8)$ alone. Kallikrein inhibitor protects glucagon from a lytic factor released into the medium by the acinar tissue [5]; it does not modify the rate of insulin secretion induced by glucose alone [5]. Before its addition to the medium, the neutral red was purified according to the method recommended by OKUDA et al. [8]. As reported by these authors and as illustrated in Fig. 1, this purified material, when injected in conscious, fed rats, causes sustained hyperglycaemia comparable with that observed after administration of exogenous glucagon.

From the fall in insulin antibody content of the medium during incubation, the insulin secretion rate was determined and is expressed in $\mu \mathrm{U}$ insulin secreted per mg incubated tissue per $60 \mathrm{~min}$. Full details of this method are reported elsewhere [6].

Presentation of Results. Media containing neutral red and control media containing glucose alone were compared in the same experiments using equal numbers $(n)$ of flasks. The mean difference (d.f. $=2 n-2$ ) in secretion rates found under these conditions is quoted here, together with the mean rate observed in the presence of glucose alone. In order to test the inhibitory effect of imidazole, in each experiment 4 groups, each of 14 flasks, were simultaneously incubated, the media

Table 1. Example of statistical analysis of the inhibitory effect of imidazole in a typical experiment. Values quoted in Table 3 correspond to the residual insulin output (*), expressed in per cent of the control value

\begin{tabular}{|c|c|c|c|}
\hline & Experimental conditions & $\begin{array}{l}\text { Insulin output } \\
(\mu \mathrm{U} / \mathrm{mg} \cdot 60 \mathrm{~min})\end{array}$ & $\begin{array}{l}\text { Inhibitory effect of } \\
\text { imidazole }\end{array}$ \\
\hline A & glucose $(3 \mathrm{mg} / \mathrm{ml})$ & $52.3 \pm 2.9(14)$ & \\
\hline B & $\begin{array}{l}\text { glucose }(3 \mathrm{mg} / \mathrm{ml}) \\
\text { imidazole }(3.3 \mathrm{mg} / \mathrm{ml})\end{array}$ & $22.0 \pm 1.8(14)$ & $-30.3 \pm 3.3(P<0.001)$ \\
\hline $\mathrm{C}$ & $\begin{array}{l}\text { glucose }(3 \mathrm{mg} / \mathrm{ml}) \\
\text { theophylline }(0.25 \mathrm{mg} / \mathrm{ml})\end{array}$ & $86.7 \pm 4.2(14)$ & \\
\hline D & $\begin{array}{l}\text { glucose }(3 \mathrm{mg} / \mathrm{ml}) \\
\text { theophylline }(0.25 \mathrm{mg} / \mathrm{ml}) \\
\text { imidazole }(3.3 \mathrm{mg} / \mathrm{ml})\end{array}$ & $27.9 \pm 2.6(14)$ & \\
\hline $\mathrm{C}-\mathrm{A}$ & $\begin{array}{l}\text { control effect of } \\
\text { theophylline }\end{array}$ & $+34.4 \pm 5.0$ & -0.0011 \\
\hline D.B & $\begin{array}{l}\text { residual effect of } \\
\text { theophylline }\end{array}$ & $+5.9 \pm 3.1$ & $(-0.001)$ \\
\hline \multicolumn{4}{|c|}{ Conclusions } \\
\hline i) & \multicolumn{3}{|c|}{$\begin{array}{l}\text { Significant inhibition by imidazole of the stimulant effect of glucose; the residual } \\
\text { effect of glucose }\left(\frac{\mathrm{B}}{\mathrm{A}}=\frac{22.0 \pm 1.8}{52.3}=\underline{42.1 \pm 3.4 \text { per cent }} \text { * is significantly different }\right. \\
\text { from zero }(P<0.001) \text {. }\end{array}$} \\
\hline (ii) & \multicolumn{3}{|c|}{$\begin{array}{l}\text { Significant inhibition by imidazole of the increase in secretion induced by theo- } \\
\text { phylline; the residual effect of theophylline }\left(\frac{\mathrm{D}-\mathrm{B}}{\mathrm{C}-\mathrm{A}}=\frac{5.9 \pm 3.1}{34.4}=\frac{17.1 \pm 9.0}{}\right.\end{array}$} \\
\hline & \multicolumn{3}{|c|}{$\underline{\text { per cent }} *)$ is not significantly different from zero $(P>0.05)$} \\
\hline
\end{tabular}

and imidazole (40 to $333 \mathrm{mg} / 100 \mathrm{ml}$; Eastman Organic Chemicals, Rochester). When glucagon was used, kallikrein inhibitor was added to both the media containing gItucagon and the control media containing glucose containing one of the following combinations: glucose alone (A); glucose and imidazole (B); glucose and either theophylline or glucagon (C); glucose, imidazole, and either theophylline or glucagon (D). The 
differences in rates of insulin secretion $(\mathrm{C}-\mathrm{A})$ and $(\mathrm{D}-$ B) represent the stimulant effect of either theophylline or glucagon, in the absence and presence of imidazole. In the presence of imidazole, the residual stimulant effect of glucose was estimated by the ratio $A / B$, and that of theophylline or glucagon by the ratio $(D-B) /$ $(\mathrm{C}-\mathrm{A})$. Table 1 illustrates this mode of calculation in a typical experiment.

\section{Results}

As is shown in Table 2, in no experimental condition could a significant effect of neutral red upon insulin secretion be detected. In most cases, the media contained glucose in high concentration $(300 \mathrm{mg} / 100$ $\mathrm{ml}$ ), because it was previously found that the stimulation of insulin secretion by exogenous glucagon is maximal under this condition [5]. It made no difference whether kallikrein inhibitor was present or not in the media (not shown in Table 2). Even when pancreatic to $80.7 \pm 4.6 \mu \mathrm{U} / \mathrm{mg} .60 \mathrm{~min}(n=42)$. Glucagon $(1.0 \mathrm{mg} /$ $100 \mathrm{ml}$ ) also caused an increase (ca. 50 per cent) of the stimulant effect of glucose, from $53.6 \pm 2.9(n=84)$ to $80.3 \pm 3.0 \mu \mathrm{U} / \mathrm{mg} .60 \mathrm{~min}(n=84)$. In the presence of low concentrations of imidazole $(40$ to $50 \mathrm{mg} / 100$ $\mathrm{ml}$ ), neither the stimulant effect of glucose alone, nor the increase in secretion provoked by theophylline was significantly modified. However, at the same concentration of imidazole $(50 \mathrm{mg} / 100 \mathrm{ml})$, the increase in secretion caused by glucagon was reduced to less than half its control value measured in the absence of imidazole. At an intermediate imidazole concentration $(100 \mathrm{mg} / 100 \mathrm{ml})$, the enhancing effect of glucagon upon insulin secretion was completely abolished, whereas both the stimulant effect of glucose alone and the increase in secretion due to theophylline were only partially inhibited. Thus, under conditions where the effect of glucagon was suppressed, glucose induced insulin secretion at a mean rate of $34.6 \pm 3.9 \mu \mathrm{U} / \mathrm{mg} .60 \mathrm{~min}$ $(n=42)$, about 4 times the basal rate of insulin secre-

Table 2. Effect of neutral red upon insulin secretion. The mean change in insulin secretion rate $(+$ or $-\mu U / m g .60$ min $\pm S E M)$ induced by neutral red is quoted together with the mean insulin output measured in media containing glucose alone. The number of observations is shown in parentheses. In most experiments, kallikrein inhibitor (625 KIU/ml) was added both to the control media containing glucose alone and to the media containing glucose and neutral red. In one case (*), pancreatic tissue obtained from fed rats was first incubated for $15 \mathrm{~min}$ in the presence of glucose $(3 \mathrm{mg} / \mathrm{ml})$, kallikrein inhibitor $(625 \mathrm{KIU} / \mathrm{ml})$ and theophylline $(25 \mu \mathrm{g} / \mathrm{ml})$, and then incubated for a further 60 min after the addition, except in the control flasks, of neutral red to the media

\begin{tabular}{|c|c|c|c|c|}
\hline Rats & $\begin{array}{l}\text { Glucose } \\
(\mathrm{mg} / 100 \mathrm{ml})\end{array}$ & $\begin{array}{l}\text { Control output } \\
(\mu \mathrm{U} / \mathrm{mg} \cdot 60 \mathrm{~min})\end{array}$ & $\begin{array}{l}\text { Neutral red } \\
(\mathrm{mg} / \mathbf{1 0 0} \mathrm{ml})\end{array}$ & $\begin{array}{l}\text { Effect of neutral red } \\
( \pm \mu \mathrm{U} / \mathrm{mg} \cdot 60 \mathrm{~min})\end{array}$ \\
\hline$\overline{\text { Fed }}$ & 150 & $29.2 \pm 3.5(18)$ & 15 & $-0.9 \pm 4.3(18)$ \\
\hline Fed & 300 & $46.9 \pm 3.0(28)$ & 4 to 5 & $+5.3 \pm 4.1(28)$ \\
\hline Fed & 300 & $45.5 \mp 3.1(54)$ & 15 to 20 & $+6.4+3.6(54)$ \\
\hline Fed & 300 & $52.7 \pm 3.7(23)$ & 30 to 40 & $+2.9 \pm 10.5(23)$ \\
\hline \multirow[t]{2}{*}{ Fasted } & 300 & $39.9 \pm 3.4(18)$ & 15 & $+1.6 \pm 5.3(18)$ \\
\hline & & $(\mu \mathrm{U} / \mathrm{mg} \cdot 75 \mathrm{~min})$ & & $( \pm \mu \mathrm{U} / \mathrm{mg} \cdot 75 \mathrm{~min})$ \\
\hline Fed & $\begin{array}{l}300(*) \\
+ \text { theophylli }\end{array}$ & $\begin{array}{l}94.3 \\
\text { ine }\end{array}$ & 15 & $-2.0 \pm 7.6(18)$ \\
\hline
\end{tabular}

tissue was first incubated for $15 \mathrm{~min}$ in the presence of kallikrein inhibitor and a low concentration of theophylline $(2.5 \mathrm{mg} / 100 \mathrm{ml})$, and then further incubated for $60 \mathrm{~min}$ after the addition of neutral red to the media, there was no stimulation of insulin secretion by neutral red. Because it has been recently claimed that isolated islets obtained from fasted rats release glucagon at a subnormal rate [11], the pancreatic tissue in one experiment was taken from rats fasted for $24 \mathrm{~h}$; but neutral red still failed to affect insulin secretion in pancreatic tissue from these fasted animals.

Table 3 and Fig. 2 summarize the results concerning the inhibitory effect of imidazole. The secretion of insulin induced by glucose alone $(300 \mathrm{mg} / 100 \mathrm{ml})$ averaged $51.2 \pm 2.2 \mu \mathrm{U} / \mathrm{mg} .60 \mathrm{~min}(n=126)$. When theophylline $(25 \mathrm{mg} / 100 \mathrm{ml})$ was present in the incubation media, the stimulant effect of glucose was increased by about 75 per cent, from $46.2 \pm 2.4(n=42)$ tion observed in the complete absence of glucose $(9.1 \pm$ $1.9 \mu \mathrm{U} / \mathrm{mg} .60 \mathrm{~min}, n=14)$. At a much higher concentration of imidazole $(333 \mathrm{mg} / 100 \mathrm{ml})$, no significant residual effect of theophylline could be detected, but the stimulant effect of glucose alone still represented 42 per cent of its control value found in the absence of imidazole.

\section{Discussion}

It has been shown here that neutral red, which is thought to provoke glucagon release from the alphacells [8], does not increase the stimulant action of glucose upon insulin secretion. This negative finding is not conclusive. Indeed, it could be argued that, despite the presence in the incubation medium of kallikrein inhibitor and despite the proximity of the alpha- to the beta-cells, the glucagon released from the alpha- 
cells was destroyed by lytic factors originating in the acinar tissue [7]. In addition, the effect of neutral red upon glucagon release has been demonstrated in vivo, but not yet in vitro. Finally, there is the possibility was not sufficient to reproduce the increase in insulin secretion that is observed when exogenous glucagon is added to the incubation media in concentrations from 0.5 to $1.0 \mathrm{mg} / 100 \mathrm{ml}[5]$.

Table 3. Effect of imidazole upon insulin secretion

a) Mean insulin output ( $\mu \mathrm{U} / \mathrm{mg} \cdot 60 \mathrm{~min}$ 上 SEM) by tissue incubated in media containing glucose alone; number of observations shown in parentheses.

b) Effects of drugs are shown as mean increases in insulin secretion rates $(+\mu \mathrm{U} / \mathrm{mg}$. $60 \mathrm{~min}+\mathrm{SEM}$ ); the number of observations is in parentheses.

c) The mean residual effects ( \pm SEM) of either glucose alone or the added drugs, in the presence of various concentrations of imidazole, are shown as per cent of their respective mean control values measured in the absence of imidazole, during the same experiment. Also shown are the number of observations (in parentheses) and the statistical significance of differences between residual and control output ( ${ }^{\mathrm{a}} P<$ $\left.0.05 ;{ }^{\mathrm{b}} P<0.02 ; \mathrm{c} P<0.005\right)$

\begin{tabular}{|c|c|c|c|c|}
\hline & $\begin{array}{l}\text { Imidazole } \\
(\mathrm{mg} / \mathrm{ml})\end{array}$ & $\begin{array}{l}\text { Glucose } \\
(3 \mathrm{mg} / \mathrm{ml})\end{array}$ & $\begin{array}{l}\text { Theophylline } \\
(0.25 \mathrm{mg} / \mathrm{ml})\end{array}$ & $\begin{array}{l}\text { Glucagon } \\
(10 \mu \mathrm{g} / \mathrm{ml})\end{array}$ \\
\hline $\begin{array}{l}\text { Control output } \\
(\mu \mathrm{U} / \mathrm{mg} \cdot 60 \mathrm{~min})\end{array}$ & NIL & $\begin{array}{l}51.2 \pm 2.2 \\
\text { (a) } \\
(126)\end{array}$ & $\begin{array}{l}+34.3 \pm 4.5 \\
\text { (b) } \\
(42)\end{array}$ & $\begin{array}{l}+26.7 \pm 4.0 \\
(b) \\
(84)\end{array}$ \\
\hline & 0.40 & $\begin{array}{l}106.9 \\
(14)\end{array}$ & $\begin{array}{l}87.9 \\
(14)\end{array}$ & \\
\hline (c) & 0.50 & $\begin{array}{l}94.5 \pm 8.7 \\
(28)\end{array}$ & & $\begin{array}{l}48.4 \\
(28)\end{array}$ \\
\hline \multirow[t]{3}{*}{$\begin{array}{l}\text { Residual output } \\
\text { (\% of control) }\end{array}$} & 0.75 & $\begin{array}{l}70.8 \\
(28)\end{array}$ & & ${ }_{(28)}^{32.1} \pm 19.9^{a}$ \\
\hline & 1.00 & $\begin{array}{c}61.5 \\
(42)\end{array}$ & $\begin{array}{c}55.8 \pm 10.5^{\mathrm{a}} \\
(14)\end{array}$ & $-2.6 \pm 22.4^{b}$ \\
\hline & 3.33 & $\underset{(14)}{42.1} \pm 3.4^{\mathrm{c}}$ & ${ }_{(14)}^{17.1} \pm 9.0^{\mathrm{c}}$ & \\
\hline
\end{tabular}

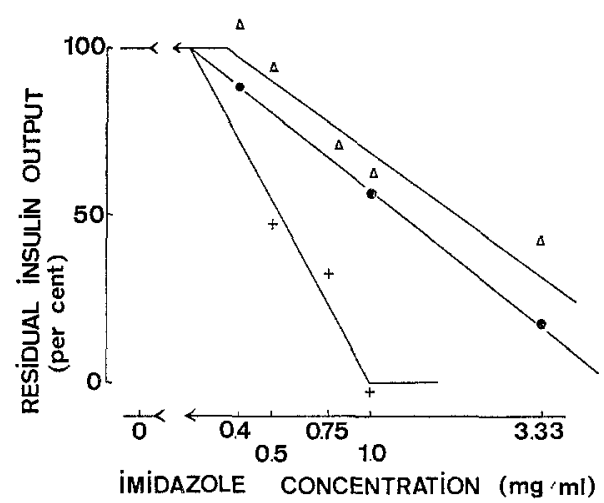

Fig. 2. Effect of imidazole upon insulin secretion induced by glucose (triangles), theophylline (circles), and glucagon (crosses). The regression lines illustrate the progressive decrease in insulin secretion rate for increasing concentrations of imidazole (ranged on a logarithmic scale). In each case, the mean residual insulin output is shown, as in Table 3 , in per cent of the mean control value measured in the absence of imidazole

that the stimulating effect of glucagon upon insulin secretion was masked by some noxious effect of neutral red upon the beta-cells. However, if one assumes that glucagon was indeed released and reached normally responsive beta-cells, the present observations would suggest that the amount of locally released glucagon
The results obtained with imidazole afford more valuable information concerning the role of glucagon in insulin secretion. First, it has been shown that imidazole inhibits the stimulant effects of glucose, glucagon, and theophylline. The range of concentrations in which imidazole exerted its inhibitory effects was comparable with that used by BUTCHER and SUTHERLAND (272 $\mathrm{mg} / 100 \mathrm{ml})$ for activation of purified phosphodiesterase [1]. Secondly, the increase of secretion induced by glucagon appeared to be more sensitive to imidazole than that induced by theophylline or glucose. This might only apply to the specific concentrations used in the present experiments, for glucose (300 $\mathrm{mg} / 100 \mathrm{ml})$, theophylline $(25 \mathrm{mg} / 100 \mathrm{ml})$, and glucagon $(1.0 \mathrm{mg} / 100 \mathrm{ml})$. It should, however, be pointed out that, under the conditions used here, each of these 3 substances exerts its maximal stimulant effect upon insulin secretion in rat pancreatic tissue [5]. Glucagon and imidazole do not act at the same enzymatic level; the great sensitivity of the glueagon effect to imidazole suggests that partial activation of the phosphodiesterase by small doses of imidazole was sufficient to compensate for the increase of $3^{\prime}, 5^{\prime}$ cyclic AMP due to activation of adenylcyclase by glucagon. On the contrary, since theophylline and imidazole are supposed to act upon the same enzyme, it is not surprising that the sensitivity of theophylline-induced insulin secre- 
tion was different from that of glucagon-induced secretion. The stimulant action of glucose appeared even more resistant to the inhibitory effect of imidazole.

Under conditions where the effect of exogenous glucagon was reduced by more than half its control value, glucose still stimulated insulin secretion at a normal rate. This finding could indicate that glucagon is not involved in the stimulant action of glucose upon insulin secretion. However, if one assumes that the sole mode of action of imidazole is to activate the phosphodiesterase, then the fact that imidazole, in higher concentrations, also inhibits the effect of glucose could well point in favour of some role played by the betacell's adenylcyclase system in the normal rate of insulin secretion evoked by glucose in pancreatic tissue.

We think therefore that the major finding emerging from the present experiments is that glucose can stimulate insulin secretion under conditions where imidazole completely abolished the effect of exogenous glucagon. Moreover, at a much higher concentration of imidazole, which also suppressed the effect of theophylline, the rate of insulin secretion induced by glucose was still more than twice the basal rate of secretion observed in the complete absence of glucose. It is therefore concluded that glucose may stimulate insulin secretion despite an apparently complete inactivation of the beta-cell's adenylcyclase system. This conclusion is consistent with the hypothesis, recently put forward [5], that $3^{\prime}, 5^{\prime}$ cyclic AMP enhances the effect of glucose upon insulin secretion, probably by activating glucose metabolism within the beta-cell, but that $3^{\prime}, 5^{\prime}$ cyclic AMP itself cannot be considered as the signal for secretion.

\section{References}

1. Butcher, R.W., and E.W. SutherLand : Adenosine $3^{\prime}, 5^{\prime}$-phosphate in biological materials. I. Purification and properties of cyclic $3^{\prime}, 5^{\prime}$-nucleotide phosphodiesterase and use of this enzyme to characterize adenosine $3^{\prime}, 5^{\prime}$-phosphate in human urine. J. biol. Chem. 237, $1244-1250$ (1962).
2. Crockford, P.M., D. Ponte, Jr., F.C. Wood, Jr., and R.H. WILLTams : Effect of glucagon on serum insulin, plasma glucose and free fatty acids in man. Metabolism 15, 114-122 (1966).

3. Kukovetz, W.R., and G. PöCH: The action of imida. zole on the effects of methylxanthines and catecholamines on cardiac contraction and phosphorylase activity. J. Pharmacol. exp. Ther. 156, 514-521 (1967).

4. Lambert, A.E., D. Vecchto, A. Gonet, B. JeanRENAUD, and A.E. RENOLD: Organ culture of foetal rat pancreas: Effect of tolbutamide, glucagon, and other substances. In: "Tolbutamide after 10 years" Proceedings of the Brook Lodge Symposium, p. 6182. Excerpta Medica Foundation, International Congress Series $\mathrm{N}^{\circ} 149,1967$.

5. Mataisse, W., F. Maraissth-Lagat, and D. Mayhew: A possible role for the adenylcyclase system in insulin secretion. J. clin. Invest. 46, 1724-1734 (1967).

6. - - and P.H. WRIGHT: A new method for the measurement of in vitro pancreatic insulin secretion. Endocrinology 80, 99-108 (1967).

7. - - P.E. LACY, and P.H. WRIGHT: Insulin secretion by isolated islets in the presence of glucose, insulin and anti-insulin serum. Proc. Soc. exp. Biol. (N.Y.) 124, 497-500 (1967).

8. OKUDA, T., and A. GRolimar: Action of neutral red on the secretion of glucagon and glucose metabolism in the rat. Endocrinology 78, 195-203 (1966).

9. Samols, E., G. MarRI, and V. Marks: Promotion of insulin secretion by glucagon. Lancet $1965 \mathrm{II}, 415-$ 416.

10. TURNER, D.S., and N. McINTYRE: Stimulation by glucagon of insulin release from rabbit pancreas in vitro. Lancet $1966 \mathrm{I}, 351-352$.

11. Vanom, J.E., K.D. BuChanan, D.R. Chatuoner, and R.H. WILIrams : Factors influencing insulin and glucagon release from isolated islets of Langerhans. Diabetes 16, $518(1967)$.

12. Vtoonio, O.D., A. LuYckx, G.R. ZAHND, and A.E. RENoLD: Insulin release induced by glucagon in organ cultures of fetal rat pancreas. Metabolism 15, 577581 (1966).

13. Wright, P.H., W. Malarsse, and I.J. Reynolds: The assay of partially neutralized guinea-pig antiinsulin serum. Endocrinology 81, 226-234 (1967).

Dr. W. Mataisse, Laboratoires de Médecine Expérimentale et d'Anatomie Pathologique, Université Libre de Bruxelles, Bruxelles, Belgique 